\title{
Angiosarcoma of Skull in a Pregnant Woman: Case Report and Review of the Literature
}

\author{
Hamile bir Kadinda Kafatasında Yerleşmiş Anjiosarkoma: \\ Olgu Sunumu ve Literatür Incelemesi
}

Mohammad SAMADIAN ${ }^{1}$, Mohammad RAKHSHAN ${ }^{2}$, Karim HADDADIAN ${ }^{1}$, Omidvar REZAEI ${ }^{1}$, Seyed Ali Modaress ZAMANI $^{1}$, Fatemeh KHORMAEE ${ }^{1}$

${ }^{1}$ Loghman-e-Hakim Medical Center, Shahid Beheshti University of Medical Sciences, Department of Neurosurgery, Tehran, Islamic Republic of Iran

${ }^{2}$ Loghman-e-Hakim Medical Center, Shabid Beheshti University of Medical Sciences, Department of Pathology, Tehran, Islamic Republic of Iran

Correspondence address: Mohammad SAMADIAN / E-mail: with:mdsamadian@hotmail.com

\begin{abstract}
Angiosarcoma is a rare tumor of bone that uncommonly involves the skull. Primary neoplasms of the skull represent $2.6 \%$ of primary neoplasms of bone. We wish to report a case of angiosarcoma of he skull in an 18-year-old pregnant woman who presented with a rapidly growing left frontotemporal mass. Neuroimaging revealed a left frontotemporal mass with destruction of diploic space and both tables and with extension to the subgaleal and epidural spaces. The patient underwent surgery and the tumor was removed totally. Histological features of angiosarcoma were seen in the pathology study. She received adjuvant chemotherapy and radiation therapy. She has remained well during 6 years of follow-up with no evidence of recurrence. Angiosarcoma is a rare malignant bone tumor of vascular origin. Our case is the only female patient with skull angiosarcoma that has been reported so far.
\end{abstract}

KEYWORDS: Angiosarcoma, Skull, Neoplasm, Tumor

öz

Anjiosarkoma nadir görülen ve kafatasını da az sıklıkta tutan bir tümördür. Kafatası kaynaklı tümörler birincil kemik tümörleri içinde yaklaşık olarak \% 2,6'lık bir yer tutar. Olgumuzda 18 yaşında hamile kadında sol frototemporal bölgeye yerleşmiş ve hızlı büyüme gösteren angiosarkoma sunulmaktadır. Görüntüleme çalışmalarında tümörün sol frontotemporal bölgede diplöe mesafesinde harabiyet yaptığı, her iki tabulayı da tuttuğu ve subgaleal ve epidural mesafelere doğru ilerlediği görüldü. Hasta ameliyat edildi ve tümör dokusunun tamamı çıkarıldı. Tümörün patolojik incelemesinde belirgin angisarkom özellikleri görüldü. Doku tanısı sonrası hastaya radyoterapi ve adjuvan kemoterapi uygulandı. Hastanın 6 yıllık izleminde rekürrensi olmadı. Anjiosarkoma nadir görülen, vasküler kökenli malin bir kemik tümörüdür. Vakamız, literatürde şu ana kadar sunulan bir kadında kafatası yerleşimli ilk anjiosarkom olgusudur.

ANAHTAR SÖZCÜKLER: Anjiosarkoma, Kafatası, Neoplazma, Tümör

\section{INTRODUCTION}

Primary neoplasms of the skull represent $2.6 \%$ of primary neoplasms of bone $(1,3)$. Primary malignant tumors of he skull are less common, accounting for only $0.8 \%$ of primary malignant neoplasms of bone (1). Angiosarcoma is a rare malignant neoplasm of bone that uncommonly involves the skull (6). We hereby report a case of angiosarcoma in a pregnant woman by describing the plain film, computed tomography (CT), and magnetic resonance imaging (MRI) as well as the histopathological findings.

\section{CASE REPORT}

An 18-year-old pregnant woman in the 20th week of gestation had a lump at the frontotemporal region of her skull two weeks after a seemingly minor head injury with a small object. She presented with increasing size of lump, headache, and vomiting.
Physical examination revealed a large, firm, tender, and fixed $(10 \times 10 \times 20 \mathrm{~cm})$ lump in her left frontotemporal region without any superficial scalp lesions or discharge. Neurologic examination revealed a right hemiparesis (muscle power: 4 out of 5), mild dysphasia and bilateral grade two papilledema. Skull X-ray showed a large $(3 \mathrm{~cm} \times 4 \mathrm{~cm})$ radiolucent lesion in the left frontotemporal region without peripheral sclerosis or other skull lesions. CT scan revealed a hyperdense mass in her left frontotemporal skull that was destroying the calvaria with expansion and erosion of diploic space, inner and outer tables with epidural and subgaleal extension. MR imaging confirmed that the lesion had diploic, subgaleal and epidural extension with cortical buckling effect and midline shift (Figure 1A,B). On MRI, the lesion was heterogeneously isointense in T1weighted and hyperintense in T2-weighted images. Contrast imaging was not performed because of pregnancy. 

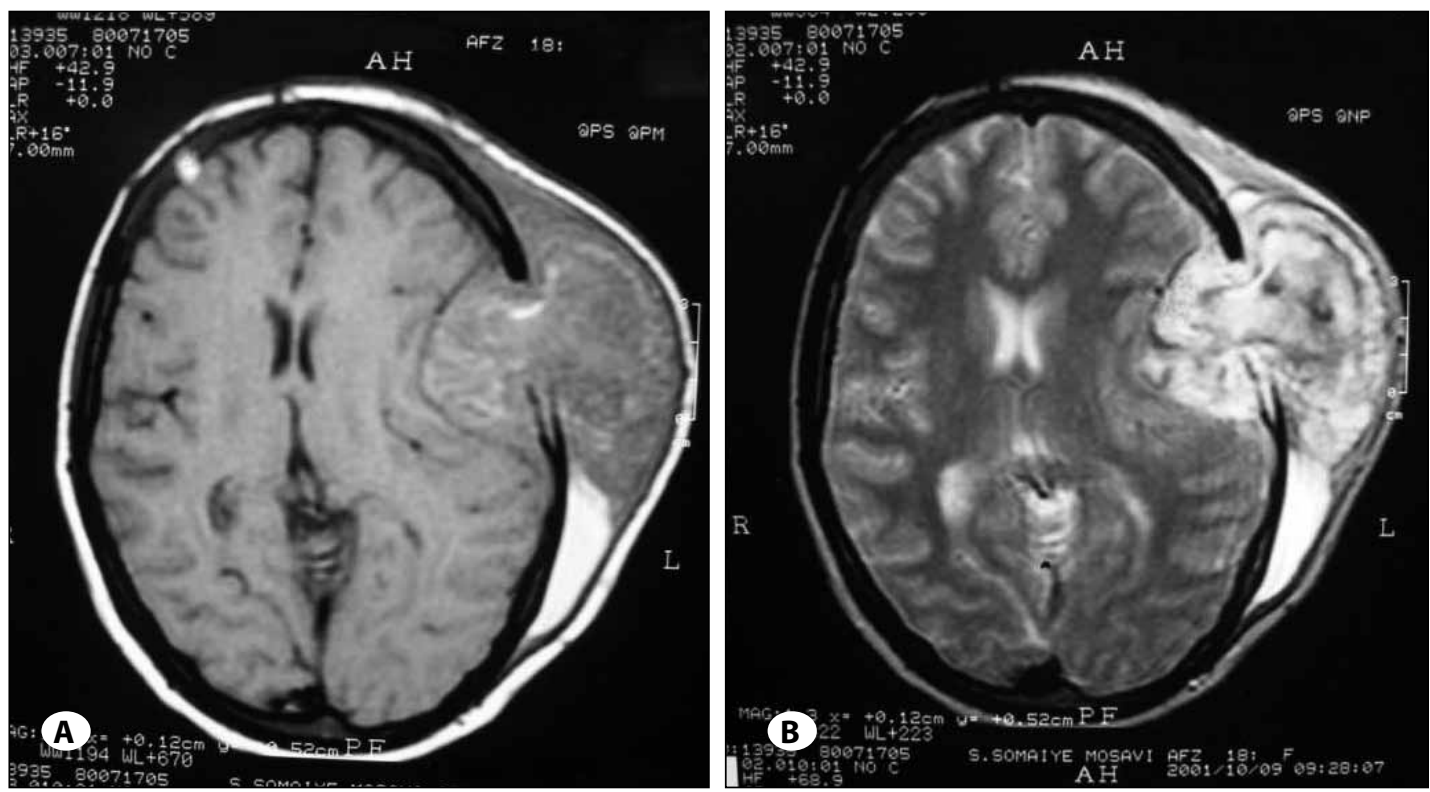

Figure 1: Axial

Brain MRI showing that the lesion had diploic, subgaleal and epidural extension with midline shift $\mathbf{A}) \mathrm{T1}$, B) $\mathrm{T} 2$.

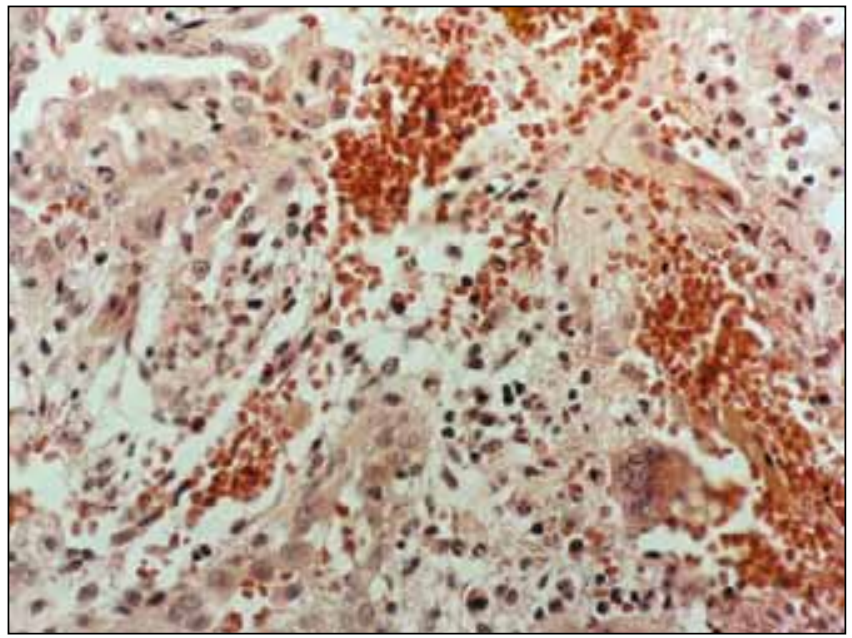

Figure 2: Pathology of lesion that shows moderately pleomorphic cells with enlarged nuclei and abundant eosinophilic cytoplasm along with solid foci of epithelioid tumor cells.

She was operated under general anesthesia. A reddish-brown hypervascular lesion with intralesional patchy hemorrhage was seen. Frozen section pathology was suspicious for angiosarcoma. Wide craniectomy up to normal bone was done. The external layer of dura mater and galea appeared involved, so we resected the dura mater and galea. The dura was repaired with fascia lata and cranioplasty was performed with bone cement.

Pathology examination of the lesion revealed variably sized, often anastomotic vascular channels lined by plump, moderately pleomorphic cells with enlarged nuclei and abundant eosinophilic cytoplasm along with solid foci of epithelioid tumor cells showing frequent mitoses (Figure 2). Immunostaining with antibody to factor VIII-related antigen was positive within the tumor cells in both the vascular and solid portions of the lesions. Following the operation, pregnancy was terminated because of the need for chemotherapy and radiation therapy. Six years after the initial presentation, the patient is doing well, with no evidence of recurrence.

\section{DISCUSSION}

Angiosarcoma is a rare malignant bone tumor of vascular origin. In one series of 1481 primary malignant bone tumors, only seven $(0.5 \%)$ were angiosarcomas. There is a 2:1 male predominance (5), with a median age of 32 years; $50 \%$ involve the long tubular bones, usually the lower extremities $(2,9)$. All ten reported cases involving the skull until now were male with an average age of 24 years (6). Our case is the only female patient with skull angiosarcoma reported so far. The usual presenting symptom of lesions not involving the skull is pain $(5,9)$, whereas in the skull it is of a local mass or swelling (6).

A rich network of anastomosing vessels lined by atypical cells characterizes the lesion. Immunohistochemistry is helpful in confirming the diagnosis by identifying the factor VIIIrelated antigen, which is a marker for vascular endothelial cells. Based on the degree of tumor cell differentiation, three histological grades can be identified (9). Tumor differentiation is more pronounced and diffuse in grade I lesions while differentiation decreases with increasing malignancy. Grade I lesions regularly have a good prognosis. They may remain stable through many years even without treatment. Treatment usually involves curettage or radiation alone. Grade II hemangioendotheliomas often have a good prognosis which is treated by resection and radiation frequently. Multicentricity is common and usually indicates grade I or II lesions. Nevertheless, there are frequently coexisting areas of both grade II and III within the same lesion, accounting for the unpredictable malignant potential and clinical behavior of grade II lesions. Some investigators have questioned 
whether low-grade lesions may indeed, step forward to high-grade lesions, hence accounting for their variable malignant potential. Grade III lesions exhibit undifferentiated pleomorphic cells with atypical mitotic figures. The main differential diagnosis histopathologically is epithelioid sarcoma. Although the malignant cells are epithelioid, they do not line vascular spaces and are not positive with factor VIII-related antigen Immunostaining. Grade III lesions are usually solitary and have an extremely poor prognosis, and are treated as osteosarcomas, with ablative surgery, adjuvant chemotherapy, and radiation (1, 2).

Our case was thought to be single grade III, and it was accordingly treated as an osteosarcoma, with excision, chemotherapy, and radiation. It has been suggested that hemangioendotheliomas of the skull have a worse prognosis than those elsewhere because of the secondary involvement of brain (6). Metastases to bone and lung are common with grade III lesions (4). This would suggest that follow-up should include MR imaging of the region of initial involvement for evaluation of recurrence, as well as bone scans and chest radiography for evaluation of metastatic disease.

Controversy exists as to the appropriate name of this entity. Many different names have been proposed (6), but the two most accepted terms are hemangioendothelioma and angiosarcoma. Hemangioendothelioma is the preferred name because angiosarcoma implies a high-grade malignancy (9) and, as noted above, not all lesions are high grade.

Plain radiographs reveal lytic lesions, maybe multiple, with no surrounding sclerosis. In the skull, the frontal region is most commonly involved (6). CT scanning shows similar findings and may demonstrate expansion of the bone because of involvement of the diploic space (6). As expected, a nuclear bone scan will show areas of increased activity (8). MR images demonstrate lesions of diploic space, with extension to inner and outer tables (7). The lesions are isointense with gray matter on T1-weighted and proton density-weighted images and of increased signal in T2-weighted images. On T2-weighted images, the lesion may have a lobulated and septated appearance, which may relate to the coalescence of multiple lesions (1).

\section{CONCLUSION}

Angiosarcomas have rarely been reported to involve the skull. Our case is the first report of such involvement in a female patient.

\section{ACKNOWLEDGEMENT}

The authors would like to thank the Farzan Institute for Research and Technology for technical assistance.

\section{REFERENCES}

1. Bourekas EC, Cohen ML, Kamen CS, Tarr RW, Lanzieri CF, Lewin JS: Malignant hemangioendothelioma (angiosarcoma) of the skull: Plain film, CT, and MR appearance. AJNR Am J Neuroradiol 17:1946-1948,1996

2. Campanacci M, Boriani S, Giunti A: Hemangioendothelioma of bone: A study of 29 cases. Cancer 46:804-814,1980

3. Doran SE, Gebarski SS, Hoff JT: Tumors of skull. In: Youmans JR, ed, Neurological Surgery. 4th edition. Philadelphia: W. B. Saunders: 1997:1996

4. Larsson SE, Lorentzon R, Boquist L: Malignant hemangioendothelioma of bone. J Bone Joint Surg Am 57: 84-89,1975

5. Lopes M, Duffau H, Fleuridas G: Primary spheno-orbital angiosarcoma: Case report and review of the literature. Neurosurgery 44:405-407, 1999

6. Shuangshoti S, Chayapum P, Suwanwela N, Suwanvela C: Unilateral proptosis as a clinical presentation in primary angiosarcoma of skull. Br J Ophthalmol 72: 713-719, 1988

7. Thananopavarn P, Smith JK, Castillo M: MRI of angiosarcoma of the calvaria. AJR Am J Roentgenol 181:1432-1433, 2003

8. Volarich DT, Impey MD, Routsong R, Cohen RF: Scintigraphic findings in angiosarcoma of the skull. Clin Nucl Med 16: 775-777, 1991

9. Volpe R, Mazabraud A: Hemangioendothelioma (angiosarcoma) of bone: A distinct pathologic entity with an unpredictable course? Cancer 49:727-736,1982 